putrid smells with the low-salt bacon; biochemical changes were accelerated generally at $30^{\circ}$. Coagulase-positive Staphylococci were found occasionally in the low-salt bacon kept at $20^{\circ}$ but did not multiply; at $30^{\circ}$ limited multiplication occurred but other bacteria reached counts 100- to 1,000-fold greater; no coagulase-positive Staphylococci were found in the bacon of higher salt-content.

Among the lactic acid bacteria making up the dominant element in the spoilage flora, several genera were distinguished: Lactobacilli, Group D Streptococci, Leuconostocs and Pediococci, besides types not precisely identified. The development of large numbers of Group $D$ Streptococci is noteworthy-it is clear that these organisms are not a valid index of fæcal pollution in this product.

Data were presented to show the gradual disappearance of nitrate and nitrite from the bacon during storage with, occasionally, a peak in nitrite production; and these changes were related to the proportions of nitrate- and nitrite-reducing Micro- cocci under the different conditions. It was remarked in discussion that this bacon contained unusually small quantities of nitrate and nitrite, so that the data could not be regarded as typical.

The striking general feature of the symposium was the contrast in treatment between the fruits and the meats. For the fruits, it was possible to discuss changes in the internal atmosphere of a package with confidence, but not for the meats. Two reasons for this difference may be suggested. First, research on the gas storage of fruits during thirty-five years has provided detailed information about their respiratory activities under a variety of atmospheric conditions and temperatures, but there are few corresponding data for meats. Secondly, while micro-organisms seldom make any significant contribution to the gaseous exchanges in a fruit pack, they sometimes do so with meats; and for the micro-organisms, also, there is a dearth of information about their activities under the relevant conditions. Here are two examples of the need for more basic research on meat. M. INGRAM

\title{
ECONOMIC ENTOMOLOGY IN AUSTRALIA
}

T

HE annual report of the Division of Entomology of the Commonwealth Scientific and Industrial Research Organization (Australia) for the year 196061 * records work in progress over a wide front. The work of the Division embraces the whole field of economic entomology but with minimum attention to short-term applied studies and particular emphasis on basic research involving long-term field and laboratory investigations.

In recent years the disadvantages of controlling insect pests solely by chemical means have become increasingly manifest in Australian agriculture as they have elsewhere in the world. Induced resistance to insecticides, the suppression of beneficial species, the accumulation of toxic residues, are making chemical control measures more and more difficult and costly to implement. Many of the insect pest problems involved are of great importance to the economy of Australia, and, as part of a long-standing policy, the Division of Entomology is investigating means of control which will circumvent the difficulties consequent on relying entirely on the use of insecticides.

New approaches are being sought to control such pests as shoep blowfly, cattle tick, codling moth, fruit-fly, phasmatids and various pasture pests. By deliberately manipulating the environment of the pest, 'natural control' factors are being utilized to limit the abundance of some of these pests. For

* Commonwealth Scientific and Industrial Research Organization. Annual Report of the Division of Entomology, 1960-61. Pp. $v+46$. (Melbourne: Commonwealth Scientific and Industrial Research Organization, 1961.) example, investigations carried out on the control of codling moth by such methods point the way to a possible solution of this and other orchard pest problems through the alteration of favourable breeding conditions by 'pest management'. Rotational grazing, strategic dipping and the use of tickresistant cattle are ecological measures which may be of increasing importance in the control of cattle tick. The mechanism of insecticide resistance in the housefly and the cattle tick continues to be studied so that insecticides and other control measures may be used to the greatest advantage.

In recent years stick insects (Phasmatidae) have been increasing in importance as pests of forests in New South Wales and elsewhere. A new field station has been established to study the ecology of the species concerned. Other established stations deal with biological control, eattle tick investigations, fruit-fly investigations, pasture pests (which means chiefly the lucerne flea and the red-legged earth mite) and locusts.

The headquarters of the Division in Canberra have a particularly impressive research programme in insect physiology and biochemistry including, among many other projects, the digestion of wool, chitin, and other resistant substances, the chemistry and hardening processes in insect cuticle, the chemistry of insect hormones. Other sections deal with population dynamics, insects and viruses (which include the development of insect tissue culture) and systematics.

V. B. WigalesworTH

\section{PREHISTORY IN NIGERIA}

T should never be forgotten that prehistory as a 1 study continues to a late date in large parts of Southern, Central and West Africa. Even when European traders had opened trading posts at various places along the sea coasts, little information as to what was happening in the interior of the continent filtered through them. Even in Nigeria, which seems to have been influenced by the Portuguese as early as the late fifteenth century, the story of what was taking place in the country was little known outside it. Modern investigators have been startled by the recent discoveries of really beautiful naturalistic sculptured heads both in terracotta (probably the earlier) and in bronze.

Who were responsible for this splendid art, and who introduced the working in bronze which is certainly not indigenous since the metal is scarcely found in the country? There seem to have been, from time to time, some east-west movements of peoples, and doubtless it is to some folk from Nubia or farther 